\title{
Chapter
}

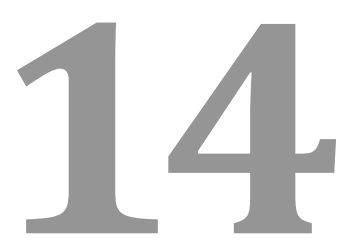

\section{ENCAPSULATION TECHNOLOGIES IN BETA CELL REPLACEMENT THERAPIES FOR TYPE 1 DIABETES}

Rahul Krishnan ${ }^{1}$, David Imagawa ${ }^{1,3}$, Clarence E. Foster III ${ }^{1,4}$, and Jonathan R.T. Lakey ${ }^{1,2 *}$

${ }^{1}$ Department of Surgery, University of California Irvine, Orange, CA 92868, USA

2 Biomedical Engineering, University of California Irvine, Irvine, CA 92697, USA

${ }^{3}$ Department of Hepatobiliary and Pancreas Surgery, University of California Irvine, Orange, CA 92868, USA

${ }^{4}$ Department of Transplantation, University of California Irvine, Orange, CA 92868, USA 


\section{Contents}

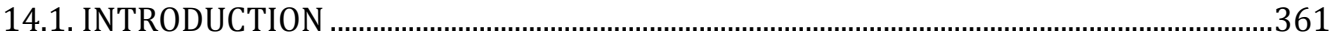

14.2. A BRIEF HISTORY OF ENCAPSULATION IN ISLET AND STEM CELL THERAPY.........362

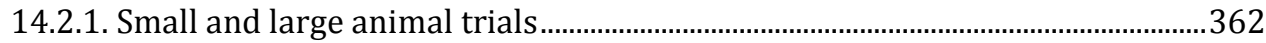

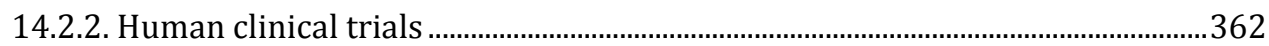

14.3. BIOMATERIAL SELECTION IN ENCAPSULATED-CELL TRANSPLANTATION.............363

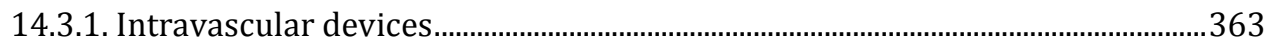

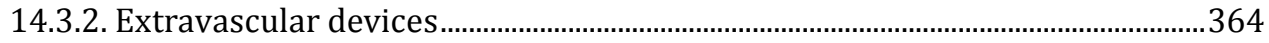

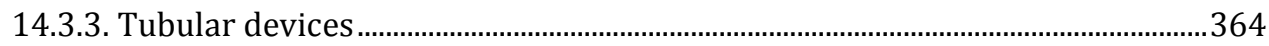

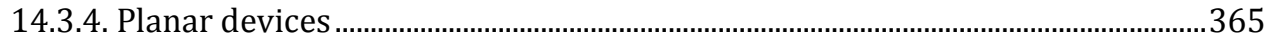

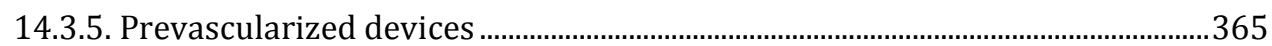

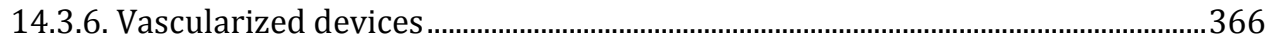

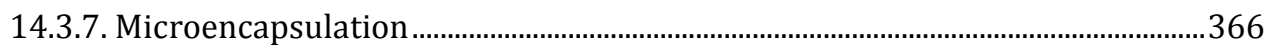

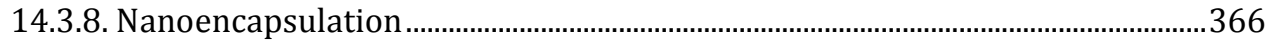

14.4. FACTORS THAT IMPACT BIOENCAPSULATION DEVICE TRANSPLANT

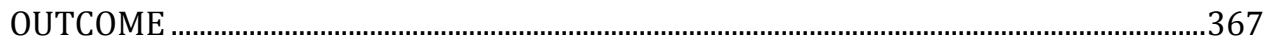

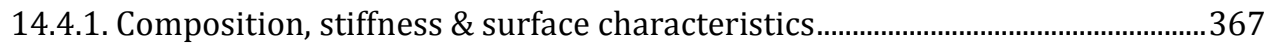

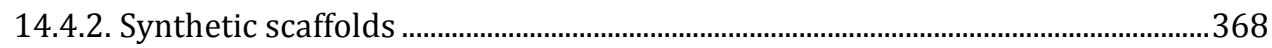

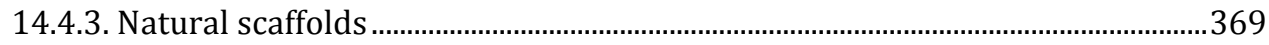

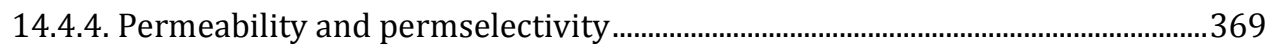

14.5. ADVANCES AND RECENT UPDATES IN ENCAPSULATION TECHNOLOGIES..............370

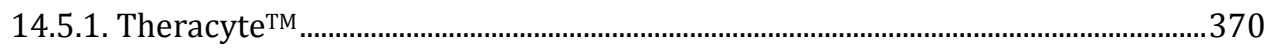

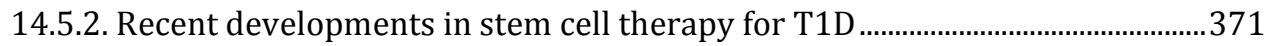

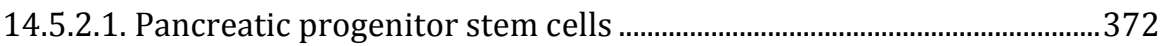

14.5.2.2. Human embryonic stem cells (hESCs)....................................................372

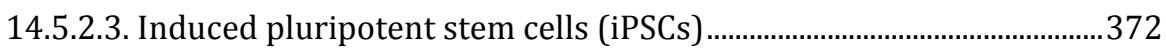

14.5.2.4. Mesenchymal stem cells (MSCs) ............................................................... 372

14.5.2.5. Adipose-derived stem cells (ADSCs) ….....................................................373

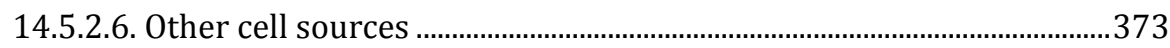

14.5.3. Bioencapsulation technologies in islet and stem cell transplant

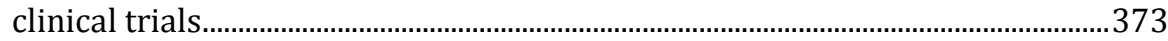

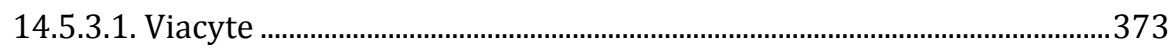

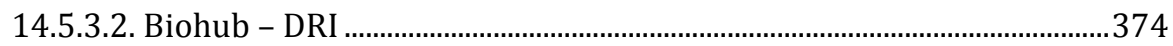

14.5.3.3. Beta- $\mathrm{O}_{2}$ ( $\beta$-air bio-artificial pancreas) ........................................................374

14.5.3.4. Sernova corp (Cell Pouch ${ }^{\mathrm{TM}}$ ) ....................................................................374

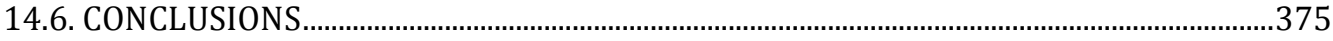

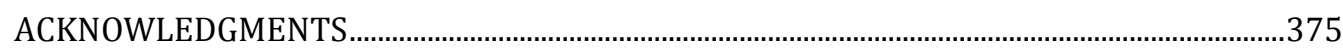

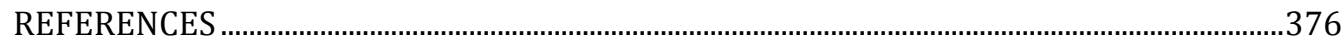




\subsection{INTRODUCTION}

Type 1 diabetes (T1D) is an autoimmune disorder characterized by $\beta$-cell dysfunction, immune-mediated $\beta$-cell destruction within the islets of Langerhans in the pancreas, resulting in a rapid decline in insulin secretion, ultimately resulting in insulin deficiency [1]. The current management paradigm for T1D is strict glycemic control through injectable exogenous insulin, often administered subcutaneously using insulin injections or pumps. An alternative to exogenous insulin administration is islet allotransplantation, a surgical procedure that attempts to replenish the depleted $\beta$-cell reserve by transplantation of islets isolated from cadaver human donors into the patient's portal vein. Over the last decade, this procedure has undergone several modifications and refinements, such that current recipients demonstrate insulin independence for a reasonable period of time.

Unfortunately, only about one in every 1000 type 1 diabetics is able to avail of this treatment modality due to scarcity of donors. Even those fortunate enough to be able to receive a transplant require islets from multiple donors. These disadvantages, coupled with inconsistent islet yields, and the need for a multi-drug immunosuppressive regimen with significant adverse effects has prevented the widespread application of this safe and efficacious therapeutic option [2]. While the problems with human islet donor scarcity seem insurmountable, the need for chronic immunosuppression can be circumvented, or at the very least, reduced by encapsulating these islets before transplantation.

Encapsulation of cells and tissue in biocompatible polymers has been extensively evaluated by the scientific community over the last three decades. Encapsulation serves to create a shield against immune cells and molecules either of which could be potentially cytotoxic, thus protecting the encapsulated tissue from immune-mediated graft rejection while still permitting the influx of glucose, amino acids, micronutrients, oxygen and the efflux of insulin, urea, metabolites and carbon dioxide. Although encapsulation was first described in 1933, research into using encapsulation technologies in developing therapies for T1D has only been prevalent over the last two decades. This chapter will provide an update on advances in this field while expounding on current trends and future directions. 


\subsection{A BRIEF HISTORY OF ENCAPSULATION IN ISLET AND STEM CELL THERAPY}

\subsubsection{Small and large animal trials}

Bisceglie et al., demonstrated in 1933 that mouse tumor cells encapsulated within a membranous biopolymer, could be transplanted safely into the abdominal cavity of a guinea pig. He observed that the cells were able to successfully evade the immune system and remained viable for several months. Today, this report is widely regarded as the first scientific document describing an attempt to transplant cells encapsulated within bioartificial membranes [3].

In 1980, Lim et al. reported that transplantation of 2,000-3,000 islet equivalents (IEQ) of islets encapsulated within alginate-poly(L-lysine)-alginate (APA) microcapsules into streptozotocin (STZ)-induced diabetic rats was able to reverse hyperglycemia for a three week period post-transplantation [4]. The hydrogel used in this study was alginate, which is an umbrella term that refers to a number of complex polysaccharides most of which are commercially extracted from seaweed, such as kelp (brown algae) and certain cases, from bacteria (Pseudomonas and Azotobacter spp.). Alginate is composed of linear, binary copolymers of $\beta$-D-mannuronic (M) and $\alpha$-L-guluronic (G) acid and at certain ratios of $M$ to $G$, alginate exhibits a favorable immunologic profile provided it has undergone extensive purification [3-5]. Several other researchers have reported that islets demonstrate prolonged function after transplantation into small [6-11] and large animals [12-17] after encapsulation. In 2000, Ramiya et al. reported the first instance where islet-like' clusters generated in vitro from pancreatic stem cells could reverse hyperglycemia in non-obese diabetic (NOD) mice [18]. In 2010, Tuch et al. demonstrated that encapsulated pancreatic progenitor cells can normalize blood glucose levels in NOD mice [19].

\subsubsection{Human clinical trials}

A few early-phase human clinical trials with alginate encapsulated islets demonstrated prolonged graft survival, reductions in hemoglobin A1C (HbA1c) levels and lower insulin requirements [20-23]. In 1994, the first clinical trial using human islets was reported where a 38 year old diabetic patient was transplanted with 10,000 IEQ $\mathrm{kg}^{-1}$ body weight alginate-encapsulated human islet allografts while also concurrently receiving low-dose immunosuppression. After transplantation, the recipient reported that he was insulin-free for 9 months [24]. In 2006, Calafiore et al. reported two subjects that received encapsulated human islets. Both demonstrated lower insulin requirements and improved glycemic profiles, but no insulin independence [25]. In 2013, Sernova Corp. (Edmonton, Canada) reported that phase I / II clinical trials on the Sernova Cell Pouch ${ }^{\mathrm{TM}}$ on 20 T1D patients demonstrated 
that the device was safe for use in a subcutaneous transplant site and demonstrated superior biocompatibility [26]. In August 2014, Viacyte Inc., a privately-held research company secured approval from the U.S. Food and Drug Administration (FDA) to conduct the first clinical trial using encapsulated stem cell-derived insulin producing cells on human patients in San Diego [27].

\subsection{BIOMATERIAL SELECTION IN ENCAPSULATED-CELL TRANSPLANTATION}

Devices used in cell encapsulation today can broadly be classified into macroscale, microscale, and nanoscale devices. These implantable devices could be implanted at intravascular or extravascular sites anywhere in the body. Several encapsulation devices currently being under evaluation are shown in Figure 1.
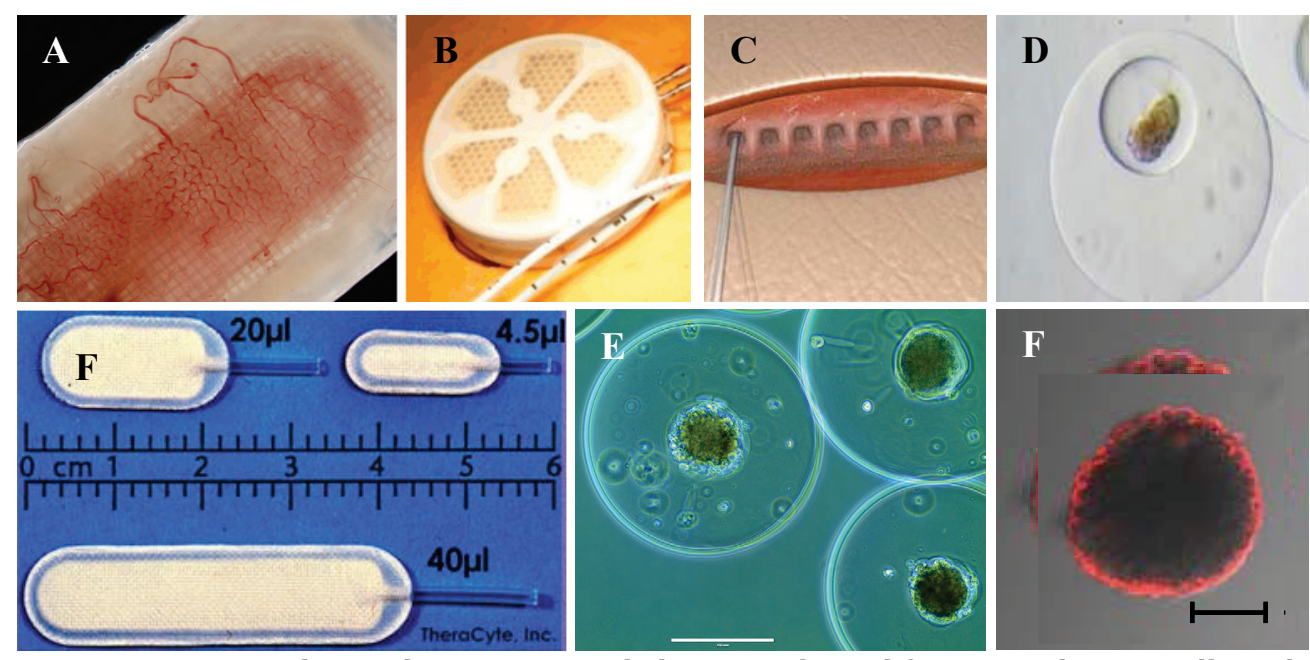

Figure 1. Encapsulation devices currently being evaluated for use with stem cells and islets. VC-01TM [185] (A). $\beta$-Air [186] (B). Sernova Cell Pouch System ${ }^{\text {TM }}$ [182]

(C). Double encapsulated islet [P. de Vos, personal communication] (D). Various TheracyteTM models [132] (E). Single encapsulated islet (F). Nanoencapsulated islet

(G) (Ricordi C, personal communication).

\subsubsection{Intravascular devices}

Intravascular devices contain islets encapsulated within biocompatible tubes or fibers which are then directly connected to the recipient's vascular system $[28,29]$. Although they present advantages over extravascular transplant sites, namely, the ability to sense instantaneous changes in blood glucose and respond appropriately and superior oxygen and nutrient diffusion facilitated 
by being directly connected to blood vessels. However, they have a predilection to trigger intravascular thrombosis at the implant site, and thus require concomitant anticoagulation therapy [30,31]. These drawbacks make them poor candidates for use in stem cell transplantation.

\subsubsection{Extravascular devices}

A majority of macroencapsulation devices [32-40] that have been evaluated for use in islet and stem cell transplantation are implanted at extravascular sites. This is because recipients do not suffer the hemorrhagic complications seen with implantable intravascular devices. Consequently, such devices have been evaluated more extensively. They may be broadly classifiable into tubular and planar devices based on their morphology.

\subsubsection{Tubular devices}

Over the last two decades, studies conducted using extravascular isletcontaining tubular devices and sealed hollow fiber devices [41-46] have demonstrated poorer outcomes compared to similar devices transplanted intravascularly. These results were presumed to be a result of inadequate oxygen and nutrient diffusion within tubular devices transplanted at extravascular sites. XM-50 Amicon hollow fiber macrocapsule implants (Amicon Corp, Danvers, MA), containing human [47] or canine islets transplanted into STZ-induced diabetic pigs and rodents respectively, demonstrated minimal fibrosis 5 months post transplantation in the peritoneal cavity, despite no immunosuppression [48]. In diabetic canine recipients, these devices demonstrated a $50 \%$ success rate in achieving insulin independence for 7-12 week period, demonstrating efficacy in large animal models [49]. Subcutaneously implanted hollow fiber implants demonstrated better glycemic control, minimal fibrotic response and better protection from the immune system when they were manufactured with smooth outer surfaces compared to implants with rough or fenestrated outer surfaces [50-53]. Prevost et al. [54] reported that AN69 hollow fiber implants containing syngeneic islets demonstrated euglycemia for a 10 week period after transplantation into STZ-induced diabetic rats. Except for a thin layer of fibroblasts, no host reaction to the implant was observed. These fibers have been reported to have neovascularization potential [55], similar to intraperitoneally transplanted, smooth surface-cellulose fibers [56]. A recent in vitro study suggested that islets encapsulated in hollow fiber-devices are adequately oxygenated, comparable to levels found within microcapsules [57]. Hollow fiber devices have several advantages; they are easy to implant, retrievable, and versatile enough to be used at subcutaneous transplant sites. However, they are susceptible to damage after transplantation in vivo and require large doses of islets to achieve insulin independence [58]; this limits their widespread applicability. 


\subsubsection{Planar devices}

Planar devices consist of two circular or rectangular flat sheets attached along a peripheral rim to obtain a chamber, within which islets or stem cells are contained. It is believed that this design offers greater stability than hollow-fiber chambers. These devices are commonly implanted in the subcutaneous tissue. Alternatively, a deeper location like the pre-peritoneal space can be chosen if their configuration and size would favor a subcutaneous location. In the case of prevascularized devices, the subcutaneous site is usually preferred, as a second procedure is often required to seed islets into the device a few weeks after the initial surgery. However, it has been observed that planar implants develop changes in shape and size after implantation [59] and studies have reported formation of a dense fibrotic capsule around these devices that ultimately results in graft failure and death [60,61]. Suboptimal nutrient and oxygen diffusion across the layers leading to reduced islet viability, poor graft function, and ultimately graft failure, limit the ability of these devices to achieve prolonged insulin independence. Despite these disadvantages, the ease with which they can be retrieved after implantation, for evaluation of cell viability [62] and function [63,64] has led to several biomaterial device engineers to prefer this conformation over all others. This includes the Sernova Cell Pouch ${ }^{\mathrm{TM}}$ (Sernova Corp, Canada), the VC-01 ${ }^{\mathrm{TM}}$ device (Viacyte LLC, San Diego, CA) and the Theracyte device (Theracyte, Laguna Hills, CA) some of which can even be modified to promote vascularization while simultaneously providing effective immunoisolation $[65,66]$.

\subsubsection{Prevascularized devices}

A 'prevascularized' device is one that is designed to increase transplant site vascularity by the administration of angiogenic factors, or by the induction of neovascularization by device preimplantation, followed by islet seeding several weeks later. Prevascularization is being evaluated as a possible solution to overcome the diffusional limitations noted with planar devices and to recreate the pancreatic vascular architecture, where islets are in close contact with the surrounding microvasculature $[67,68]$. Several studies have reported successful reversal of diabetes after implantation of prevascularized islet-containing devices in the peritoneal cavity, specifically in the greater omentum or other sites; subcutaneous implantation remains the most attractive location, and represents the safer, less invasive alternative with minimal adverse effects that also allows for continuous monitoring and effortless device retrieval $[69,70]$. Pepper et al. demonstrated that even in the absence of a device, prevascularization of a subcutaneous transplant site reversed hyperglycemia in over $90 \%$ of diabetic mice after syngeneic islet transplantation [71]. Thus, the efficacy of this strategy cannot be overlooked, especially if the stem-cell containing device is being implanted in the subcutaneous space. 


\subsubsection{Vascularized devices}

Over the last decade, researchers began devising 'vascularized' devices to improve nutrient and oxygen delivery to the islets, thus improving insulin release and increasing success rates after encapsulated islet transplantation. In order to achieve vascularization, researchers first implant a 'scaffold', usually a several days or weeks before stem cell implantation. The scaffold promotes neovascularization - the genesis of new capillaries in and around, and in some instances, into the implant - and helps ameliorate hypoxic injury to the cells, especially during the first few days after transplantation when they are most vulnerable to hypoxic stress. Studies evaluating poly(tetrafluoroethylene) (PTFE) scaffolds either alone [72], or coated with acidic fibroblast growth factor (a-FGF) [73] (implanted into recipient animals four weeks before seeding with islets) concluded that, in both cases, vascularization was induced at both the subcutaneous and peritoneal locations. After the islets were seeded, the diabetic recipients were noted to demonstrate sustained normoglycemia for up to 180 days after transplantation.

\subsubsection{Microencapsulation}

In the case of microencapsulation, islets are encapsulated inside micron-sized spherical devices made of alginate, agarose or another biocompatible material and implanted into the recipient. Compared to planar and tubular macro-scale devices, alginate microcapsules are less likely to deform due to mechanical forces after transplantation, are simple to construct, easy to administer, can be scaled to meet commercial needs, and most importantly, can be easily manipulated to adjust size and permeability. Consequently, they are the most popular bioencapsulation devices [74-76] being evaluated for use in islet and stem cell encapsulation. Since these capsules can be produced in large numbers using commercially developed air-pressure driven electrostatic droplet generators [77,78], they are inexpensive, and can be standardized for use with islets or stem cells. Their safety and efficacy has been evaluated in numerous small [79] and large animal trials [80] where reversal of experimentally-induced hyperglycemia was noted without the need for immunosuppressive therapy. Their safety has already been tested in a handful of human clinical trials [81]; they are safe for widespread application in clinical transplantation. Chayosumrit et al. reported that microencapsulation promoted differentiation of human embryonic stem cells (hESCs) into definitive endoderm and prevented the formation of teratomas after transplantation in animal models [82].

\subsubsection{Nanoencapsulation}

Nanoencapsulation is achieved by enveloping the stem cell or islet in a nano-scale immunoprotective layer that is conformally coated on the cell surface, thus significantly reducing diffusion barriers and permitting implantation into 
sites normally not considered feasible [83]. This technique has several notable advantages over conventional micro- and macroencapsulation technologies, especially, rapid glucose response time, improved nutrient access, and the ability to control capsule permeability by adjusting the thickness and composition of the encapsulation layer without significantly increasing the size of the encapsulation coating. 'PEG'ylation or coating islets with poly(ethylene glycol) (PEG) is the most popular method of nanoencapsulation currently being evaluated in islet transplantation trials [84]. Exposure to ultraviolet or visible light enables PEG cross-linking resulting in the formation of a conformal coat (or nanocapsule) around the stem cell or islet with minimal tissue damage [85]. However, PEG-encapsulation is ineffective in protecting islets from cytokine-mediated cell injury and it has also been demonstrated that PEG is less biocompatible than alginate and similar hydrogels [86]. Nanolayers composed of alginate and chitosan [158], membranes made of polylysine and poly(glutamic acid) [87], poly(L-lysine)-poly(ethylene glycol) (biotin) (PPB) and streptavidin (SA) [160], complement receptor-1 and heparin [88], and PEG lipid and poly(vinyl alcohol) (PVA) $[89,90]$ are some of the many biomaterials currently being evaulated for use in stem cell and islet nanoencapsulation.

\subsection{FACTORS THAT IMPACT BIOENCAPSULATION DEVICE TRANSPLANT OUTCOME}

\subsubsection{Composition, stiffness \& surface characteristics}

Results from several in vivo studies have demonstrated that implant survival after encapsulation within biomaterials is heavily influenced by implant composition and surface. King et al. demonstrated that when islets were encapsulated within poly(L-lysine)-free (PLL-free) high mannuronate alginate (high M) capsules, they demonstrated sustained normoglycemia (up to 8 weeks) compared to high guluronate (high G) alginate capsules [91]. However, it has also been reported that high M, but not high G, alginate microcapsules stimulated increased pro-inflammatory cytokine release by monocytes, specifically TNF- $\alpha$, IL- 1 , and IL- 6 , that would negatively impact islet survival $[92,93]$. Lanza et al. concluded that improved capsule stability, and prolonged graft function and survival could be achieved by increasing the concentration of alginate (from $0.75 \%$ to $1.5 \%$ ) used for encapsulation [94].

The length and sequence of mannuronate and guluronate chains and ratio of mannuronate to guluronate (M/G ratio) in alginate hydrogels determines the mechanical strength, elasticity, durability, permeability, and swelling characteristics of the alginate $[95,96]$. Wilson et al. reported that encapsulation within high $G$ alginate inhibited murine embryonic stem cell (mESC) differentiation while high $\mathrm{M}$ alginate promoted differentiation toward a primitive endoderm phenotype [97]. Thus, encapsulation material composition 
can be used to direct stem cell fate down the desired lineage. Several chemical modifications to alginate composition have either positive or undesirable effects on its biocompatibility. The use of divalent cations $\left(\mathrm{Ca}^{2+}, \mathrm{Ba}^{2+}\right)$, polycations (poly(L-lysine) or poly(L-ornithine)), and poly-electrolytes in alginate synthesis has been extensively studied $[98,99]$. APA capsules provide superior permselectivity, i.e. selective blocking of antibody entry into microcapsules [100,101]. They are also more stable and possess superior mechanical strength. Unfortunately, their use is associated with increased pericapsular cellular overgrowth [102,103], and macrophage activation $[104,105]$, both of which are attributed to greater antigenicity $[106,107]$.

Crosslinking alginate using divalent cations like barium or calcium eliminates these disadvantages. This is because crosslinking results in the formation of elastic alginate capsules with better stability and superior mechanical strength $[108,109]$. Barium crosslinking has been reported to be less immunogenic [110] than APA (or other polycation-linked) capsules, while providing sufficient protection from antibody and cytokine-mediated islet-damage. These results were surprising as they were previously shown to be more permeable to IgG antibodies than APA capsules [111].

Candiello et al. demonstrated that hESC gene expression was influenced by changes in the stiffness of the alginate hydrogel used. Gene expression of markers specific for the endodermal lineage were highly sensitive to small changes in substrate stiffness and it was hypothesized that substrate stiffness could be manipulated along with chemical signals to direct stem cell-lineage fates toward endodermal lines [112].

One study demonstrated that hollow fiber devices [113] with surface irregularities can trigger fibroblast activation and attachment which consequently lead to fibrosis and implant failure. It is expected that most planar and microencapsulation devices would demonstrate minimal fibroblast activation and fibrosis owing to their smooth outer layers. It has been reported that the geometry, rigidity and surface characteristics of biomaterial devices greatly influence macrophage proliferation and surface irregularities in the order of a few microns could trigger their differentiation into inflammatory phenotypes [114].

\subsubsection{Synthetic scaffolds}

Although alginate remains the most popular hydrogel of choice, agarose [115,116], chitosan [117], methacrylic acid [118], methyl methacrylate [119], polyamide [120,121], PVA [122], PEG [123,124], 2-hydroxyethyl methacrylate (HEMA) [125,126], AN69 (a copolymer of acrylonitrile and sodium-methallyl sulfonate) [127], and collagens type I and IV [128] are all being evaluated for use in islet and stem cell encapsulation. Stimuli-responsive synthetic hydrogels are commonly employed in cell encapsulation and tissue engineering. These include poly(vinylmethyl ether), polyacrylamide gels, PVA, polyphosphazene, 
and other derivatives [129]. The single biggest drawback with synthetic biomaterials is their lower biocompatibility, i.e. they are more likely to engender a brisk host inflammatory response, leading to fibrosis, graft failure and cell death. Since these materials will ultimately be transplanted into humans, all synthetic constituents would need to pass extensive toxicological evaluation and the material as well as the manufacturing process cannot, at any stage of the process, use chemicals that are known carcinogens or toxic to humans. Most synthetic devices are typically modified to interact favorably with the environment and in certain cases, designed to degrade gradually under physiologic conditions.

\subsubsection{Natural scaffolds}

Unlike their synthetic counterparts, hydrogels derived entirely from natural sources (gelatin, fibrin, agarose, hyaluronate, chitosan, and alginate) are much less likely to induce a fibrotic or inflammatory host response, and are preferred for use in microencapsulation [130,131]. Alginate is the most common hydrogel, synthesized from naturally-derived sources, used in the generation of microcapsules. However, naturally-occurring hydrogels also have certain disadvantages: lower tensile strength, greater costs, larger lot-to-lot variability, and the need for extensive purification to get rid of contaminants, all of which significantly affect costs and affect optimization of the manufacturing process [132].

\subsubsection{Permeability and permselectivity}

Choosing the appropriate pore size is vital for the success of any bio-artificial encapsulation device. An exceedingly small pore size may impede inward nutrient and oxygen diffusion, and outbound insulin and metabolite diffusion from the inner cellular zone of the device. In contrast, a particularly large pore size may be unable to prevent immunoglobulins entry, which would lead to immune-mediated islet injury. This parameter is thus the single most important determinant of biomaterial device composition and design. Colton et al. observed that when mouse insulinoma cell clusters (MIN6) encapsulated in $1 \%$ agarose, $0.005 \%$ HEMA, and $0.15 \mathrm{mg} \mathrm{ml}^{-1}$ collagen and seeded into planar nuclepore membrane devices with various pore sizes $(100-600 \mu \mathrm{m})$ - were transplanted into diabetic Wistar rats, sustained reversal of hyperglycemia was only seen at small pore-sizes $(100-200 \mu \mathrm{m})$; with larger pore sizes $(>200 \mu \mathrm{m})$ hyperglycemia reversal was partial and short-lived [133-135].

Studies have also demonstrated that exposure to host defenses significantly alters membrane permeability and nutrient diffusion across the device-host interface. Kessler et al. devised experiments where they applied a protein coat to the encapsulation device, evaluated membrane permeability to glucose and insulin during in vitro culture and implanted the devices into rats for a one 
week period. While no adherent, inflammatory or necrotic cells or fibrin deposits were noted in uncoated devices implanted in vivo (controls), protein adsorption onto the devices after implantation was greater than that noted during in vitro culture [136]. Glucose and insulin diffusion rates across the capsule surface were significantly lower in the implanted capsules, indicating that protein adsorption onto the capsule surface negatively impacts capsule permeability in vivo.

\subsection{ADVANCES AND RECENT UPDATES IN ENCAPSULATION TECHNOLOGIES}

Although encapsulation should theoretically ensure total isolation from the host's immune system and unfettered oxygen and nutrient influx across the host-device interface, in reality, graft rejection and hypoxia-induced injury are routinely observed [137,138]; this has led researchers to postulate that hypoxic-injury and cytokine-induced apoptosis are to blame. Some researchers have addressed these issues by employing layer-by-layer (LBL) nanoencapsulation, which involves the generation of several nano-scale coats by layering them over previous coats, thus enveloping the stem cells to achieve adequate immunoisolation while maintaining the diffusion distance to a minimum. LBL nanoencapsulation with multiple layers of polyelectrolyte [139] or PVA conjugated to a single layer of PEG-phospholipid [140] is also being investigated. LBL encapsulation has also been attempted in novel areas such as delayed-release pharmacotherapy and antioxidant drug delivery.

Incorporation of biological factors like fibroblast growth factor 1 (FGF-1) [141], vascular endothelial growth factor (VEGF) [142], anti-coagulants [143], anti-inflammatory molecules [144-148], immunoregulatory biomolecules like CXCL12 [149] and co-encapsulation with tolerogenic mesenchymal stem cells [150] are all currently being investigated to improve bioencapsulation device outcomes.

Several novel strategies to ameliorate hypoxia in encapsulated cells including the use of oxygen-generating chemicals [polydimethylsiloxane (PDMS)-encapsulated solid calcium peroxide] [151], co-encapsulation with photosynthetically-active microorganisms (Synechococcus lividus) [152] and implantable devices fitted with access ports to enable direct $\mathrm{O}_{2}$ delivery - the $\beta$-Air device [153] - are all being evaluated.

\subsubsection{Theracyte ${ }^{\mathrm{TM}}$}

The Theracyte device (Theracyte Inc., San Clemente, CA) is a durable and retrievable planar macroencapsulation device that consists of a biocompatible bilayer polymer membrane - a $5 \mu \mathrm{m}$ PTFE outer layer with a polyester mesh attached, laminated onto a $0.45 \mu \mathrm{m}$ inner PTFE layer [154]. At one end of the 
device, a polyethylene port provides access to the lumen for islet seeding. When implanted subcutaneously, the outer membranes induce neovascularization while the cell-impermeable inner membranes contain the insulin-releasing cells within [155]; this arrangement avoids contact with the host immune cells while improving oxygen and nutrient diffusion into the device.

Kumagai-Braesch et al. demonstrated that islet-containing Theracyte ${ }^{\mathrm{TM}}$ devices restored and sustained euglycemia in non-immunosuppressed alloimmunized diabetic rats after transplantation for a 6 month period [156]. Lee et al. demonstrated for the first time that human fetal pancreatic islet-like cell clusters could be matured in vivo after encapsulation within TheracyteTM devices. The encapsulated clusters demonstrated amelioration of hyperglycemia in diabetic immunodeficient and non-obese diabetic (NOD) mice [157]. Motte et al. reported that hESCs encapsulated within TheraCyte ${ }^{\mathrm{TM}}$ demonstrated enrichment in $\beta$-cell content as opposed to alginate microcapsules which demonstrated increased $\alpha$-cell content [158]. Kirk et al. demonstrated reversal of hyperglycemia in diabetic mice 20 weeks after transplantation of hESCs encapsulated within the devices [159].

\subsubsection{Recent developments in stem cell therapy for T1D}

Stem cells are an attractive alternative to human islets, as the scarcity of transplant-quality islets from human cadaver donors, the need for several donors to fulfil the islet requirements of each recipient, and inconsistent and unreliable islet yields with human donor pancreases preclude the application of human islet allotransplantation to all patients diagnosed and currently living with T1D. Pancreatic stem cells [160,161], hESCs [162-164], induced pluripotent stem cells (iPSCs) [165-169], mesenchymal [170-174] and adipose-derived stem cells (ADSCs) $[175,176]$ have all been used to derive islet-like cell clusters or insulin-producing cells (IPCs) that are viable, express markers similar to terminally differentiated $\beta$-cells (Insulin, GLUT2) and are able to respond to a glucose challenge. These cells have all demonstrated good function after encapsulation within bioencapsulation devices and several in vivo studies have also been conducted. Some research groups that were able to observe favorable outcomes have also applied and secured approval for phase I clinical trials in humans [166].

Mason et al. reported that embryonic pancreatic precursor cells that were dissociated, cultured in vitro, and photoencapsulated, within a synthetic PEG hydrogel preferentially differentiated into insulin-secreting $\beta$-cells. This seems to suggest that embryonic pancreatic precursor cells could be induced to proliferate and differentiate along the endodermal lineage to generate a population of glucose-responsive $\beta$-cells if exposed to specific chemical environments [177]. 


\subsubsection{Pancreatic progenitor stem cells}

In 2005, Todorov et al. reported the existence of multipotent pancreatic progenitor cells that could be successfully differentiated into insulin-producing cells [160]. A year later, Noguchi et al. reported the induction of pancreatic progenitor cells into insulin-producing cells, albeit with the use of adenoviral gene transfer [161]. While this was a significant breakthrough, the need for transgenic vectors to achieve this transition was a significant drawback.

\subsubsection{Human embryonic stem cells (hESCs)}

In 2012, Schulz et al. reported that a scalable manufacturing process for producing pancreatic progenitor cells which could reverse STZ-induced hyperglycemia in mice $4-5$ months post-transplant had been developed [162]. In 2014, Pagliuca et al., and Rezania et al. both reported successful validation of a seven-stage protocol to generate insulin-secreting cells that were able to reverse hyperglycemia in diabetic mice within months after transplantation $[163,164]$. These recent developments represent significant breakthroughs in developing a cure for T1D using hESC transplantation.

\subsubsection{Induced pluripotent stem cells (iPSCs)}

iPSCs have demonstrated the ability to differentiate into functional $\beta$-cells, in vitro [165]. iPSCs derived from mice and rhesus monkeys have demonstrated the ability to differentiate into glucose-responsive insulin-positive cells, resulting in a complete reversal of experimentally induced hyperglycemia after transplantation in diabetic mice (type 1 and 2) [166]. Jeon et al. reported successful generation of iPSCs from NOD-mouse fibroblasts and differentiation of these iPSCs into glucose-responsive insulin-producing cells which when transplanted into diabetic mice resulted in engraftment and reversal of hyperglycemia [167]. Recently, Shahjalal et al. and Kudva et al. reported successful differentiation of human-derived iPSCs into insulin-producing cells without using xenogeneic products or viral transgenic vectors respectively [168]. However, Thatava et al. suggested that translation of results observed in mice might face significant challenges before translation to humans when he reported that iPSCs isolated from T1D patients exhibited significant variations in their ability to differentiate into insulin-expressing islet-like cells [169].

\subsubsection{Mesenchymal stem cells (MSCs)}

MSCs have long been reported to have immunomodulatory properties. Yeung et al. reported that culture of MSCs with human islets could protect islets from pro-inflammatory cytokine-induced $\beta$-cell apoptosis [170]. Liu et al. reported that co-transplantation of islets with MSCs could potentially control graft inflammation as MSCs are known to secrete anti-inflammatory cytokines and also induce tolerance by suppressing Th1 lymphocytes and enhancing 
regulatory $\mathrm{T}$ cell differentiation [171]. Their immunoregulatory properties are partly due to the fact that they secrete interleukin 10 (IL-10), leukemia inhibitory factor (LIF) and other immunomodulatory biomolecules. Carlsson et al. reported that new-onset T1D patients treated with autologous MSCs showed preserved or even increased C-peptide peak and area under the curve (AUC) values. MSCs may thus play a role in preservation of $\beta$-cell mass and function and halting disease progression in T1D [172].

\subsubsection{Adipose-derived stem cells (ADSCs)}

Jun et al. reported that co-culturing ADSCs with islets may protect the islets from hypoxic injury during culture, and that this strategy could be employed to improve islet cell survival and function prior to transplantation. This hypothesis was based on the observation that mice transplanted with ADSC co-cultured islets remained normoglycemic longer and required a lower islet mass to reverse diabetes [173]. Chandra et al. reported that ADSC-derived islet-like cell aggregates (ICAs) release human C-peptide in a glucose-responsive manner and transplantation ICAs into STZ-diabetic mice restored normoglycemia within a 4 week period [174].

\subsubsection{Other cell sources}

In addition to all the aforementioned cell types, pancreatic epithelial cells, ductal cells [175,176], exocrine cells [177], $\alpha$-cells (transdifferentiation) [178], and even skin fibroblasts [179] have been demonstrated to be able to differentiate into $\beta$-cells under appropriate conditions.

\subsubsection{Bioencapsulation technologies in islet and stem cell transplant clinical trials}

\subsubsection{Viacyte}

In 2006, D'Amour et al. (Novocell Inc. San Diego, CA) reported development of a differentiation process that converted hESCs to endocrine cells which expressed insulin, but were only minimally responsive to glucose [180]. In 2008 , the same group reported the development of glucose-responsive insulin secreting cells generated from hESCs [181]. In 2012, Schulz et al. reported that their team at Viacyte LLC (San Diego, CA), had developed a scalable manufacturing process for producing pancreatic progenitor cells which could reverse STZ-induced hyperglycemia in mice 4-5 months post-transplant [182]. In 2014, Viacyte secured approval to conduct the first ever phase I safety, tolerability and efficacy study on T1D patients in the USA using hESCs encapsulated within a macroencapsulation device (VC-01 ${ }^{\mathrm{TM}}$ ) [183]. 


\subsubsection{Biohub - DRI}

In August 2014, the Diabetes Research Institute in Miami, Florida obtained FDA approval to conduct Phase I/II clinical trials to evaluate the safety and efficacy of transplanting human islets within a 'biodegradable scaffold' that can be safely transplanted in the omentum - a flap of adipose tissue found in the abdomen. The scaffold is created using the patient's plasma. After the islets are seeded in the scaffold, it will then be attached to the omentum using thrombin surrounding which an omental 'pouch' will be created to secure the implant. However, it is worth noting that this 'scaffold' is not immunoprotective, and the patient will require conventional immunosuppression to prevent graft rejection [184].

\subsubsection{Beta- $\mathrm{O}_{2}$ ( $\beta$-air bio-artificial pancreas)}

In 2010, Ludwig et al. reported sustained viability, function and immunoprotection after allogeneic subcutaneous transplantation in non-diabetic Göttingen minipigs [185]. In 2013, the same group reported normalization of blood glucose values in diabetic rodents over a 6 month period post transplantation [186] and reversal of hyperglycemia in diabetic Sinclair pigs for a 90 day period [187]. A pilot clinical trial performed in a 63 year old T1D patient demonstrated persistent islet function 10 months post transplantation without any immunosuppressive therapy [188].

\subsubsection{Sernova corp (Cell Pouch ${ }^{T M}$ )}

The Cell Pouch ${ }^{\mathrm{TM}}$ is currently undergoing an open label, non-randomized, Phase I/II safety and efficacy study of up to 20 patients with T1D undergoing allograft pancreatic islet transplantation in Canada. In 2013, Shapiro et al. reported that the first group of patients implanted with the Cell Pouch ${ }^{\mathrm{TM}}$ and transplanted with insulin-producing islets showed longer-term safety and biocompatibility with one patient beyond the 180 day time point [189].

Despite all exciting developments until multi-center, multidisciplinary, randomized, controlled, clinical trials report favorable outcomes, treatment modalities for patients with T1D remain limited.

The two principal issues of concern are:

1. The inherent propensity of hESC/iPSCs to proliferate in an unpredictable manner and undergoing malignant transformation.

2. Immune-mediated allogenic sensitization and subsequent graft rejection.

However, if these stem cell-derived insulin- producing cells are enclosed within protective, bioinert devices and implanted at appropriate sites, teratoma formation can be prevented and long-term maintenance of euglycemia can be achieved [190]. 


\subsection{CONCLUSIONS}

The management of T1D in most patients currently only involves regular blood glucose monitoring and insulin self-administration by patients either by means of injections or through an implanted insulin pump. Cell encapsulation within bioengineered devices and the insulin-producing cells derived from stem cells are two cutting-edge strategies that challenge such traditional treatment paradigms in the management of T1D and aim to revolutionize clinical islet transplantation [191]. Bioencapsulation devices may either be macroscopic as in the case with Viacyte ${ }^{\circledR}$ and $\beta$-air ${ }^{\circledR}$ or microscopic as in the case of Diabecell ${ }^{\circledR}$. Future devices may be implanted under the skin, into the omentum or dispersed into the abdominal cavity. They might be implanted after a period of pre-vascularization to improve transplant outcomes or might concurrently allow for the delivery of angiogenic and immunomodulatory biomolecules, generate oxygen locally so as to augment tissue oxygen delivery and allow for easy retrieval of the device. They might contain mesenchymal or ADSCs in addition to insulin-producing cells to support engraftment and prolong cell survival. While encapsulation technologies aim for cure, strategies to reduce insulin dependence, hypoglycemia unawareness and eliminate episodes of hypoglycemic attacks while retarding end organ damage are also key determinants in deciding which bioencapsulation technologies are best suited for clinical translation.

Stem cell therapy has been repeatedly shown to possess limitless potential as it eliminates the primary impediment to widespread application of curative strategies for T1D - a lack of healthy, viable and functional donor islets. Several novel strategies to prevent recognition and ultimate destruction by the host immune system have been designed and are currently being evaluated. However, several challenges still remain unaddressed. Advances in bioencapsulation technologies and biomaterial manufacturing, and improvements in islet and stem cell yields and insulin release parameters, along with the development of standard operating procedures (SOP), quality control measures and stringent guidelines and are vital to achieve seamless translation of these promising therapies to clinical practice with the ultimate goal of reduced patient morbidity, mortality, better quality of life and long-lasting insulin independence [192].

\section{ACKNOWLEDGMENTS}

This work was supported by the Department of Surgery, University of California Irvine and the Juvenile Diabetes Research Foundation (17-2013-288). We are grateful to Drs. Paul de Vos and Camillo Ricordi, for providing us with images of multi-layer alginate capsules and nanoencapsulated islets.

Disclosures: The authors report no conflict of interests. 


\section{REFERENCES}

1. American Diabetes Association. Diabetes Care 27(Suppl 1) (2004) S5-S10.

2. R.M. Shenkman, J.J. Chalmers, B.J. Hering, N. Kirchhof, K.K. Papas.

Tissue Eng. Part C Methods 15 (2009) 147-156.

3. V. Bisceglie. Ztschr. F. Krebsforsch 40 (1933) 122-140.

4. E.S. O’Sullivan, A.S. Johnson, A. Omer, J. Hollister-Lock, S. Bonner-Weir, C.K. Colton, G.C. Weir. Diabetologia 53 (2010) 937-945.

5. A.R. Kim, J.H. Hwang, H.M. Kim, H.N. Kim, J.E. Song, Y.I. Yang, K.H. Yoon, D. Lee, G. Khang. J. Biomater. Sci. Polym. Ed. 24 (2013) 1084-1098.

6. G. Langlois, J. Dusseault, S. Bilodeau, S.K. Tam, D. Magassouba, J.P. Halle. Acta Biomater. 5 (2009) 3433-3440.

7. F. Lim, A.M. Sun. Science 210 (1980) 908-910.

8. W. Cui, G. Barr, K.M. Faucher, X.L. Sun, S.A. Safley, C.J. Weber, E.L. Chaikof. Transplant. Proc. 36 (2004) 1206-1208.

9. M. Lamb, R. Storrs, S. Li, O. Liang, K. Laugenour, R. Dorian, D. Chapman, H. Ichii, D. Imagawa, C. Foster S. King, J.R.T. Lakey. Transplant. Proc. 43 (2011) 3265-3266.

10. Z.P. Lum, I.T. Tai, M. Krestow, J. Norton, I. Vacek, A.M. Sun. Diabetes 40 (1991) 1511-1516.

11. S. Veriter, J. Mergen, R.M. Goebbels, N. Aouassar, C. Gregoire, B. Jordan, P. Leveque, B. Gallez, P. Gianello, D. Dufrane. Tissue Eng. Part A 16 (2010) 1503-1513.

12. H. Yang, W. O’Hali, H. Kearns, J.R. Wright. Transplantation 64 (1997) 28-32.

13. Z.L. Zhi, A. Kerby, A.J. King, P.M. Jones, J.C. Pickup. Diabetologia 55 (2012) 1081-1090.

14. D. Dufrane, R.M. Goebbels, P. Gianello. Transplantation 90 (2010) 1054-1062.

15. D. Dufrane, R.M. Goebbels, A. Saliez, Y. Guiot, P. Gianello. Transplantation 81 (2006) 1345-1353.

16. R.B. Elliott, L. Escobar, P.L. Tan, O. Garkavenko, R. Calafiore, P. Basta, A.V. Vasconcellos, D.F. Emerich, C. Thanos, C. Bambra. Transplant. Proc. 37 (2005) 3505-3508.

17. P. Gianello, D. Dufrane. Bull. Mem. Acad. R. Med. Belg. 162 (2007) 439-449.

18. G. Basta, P. Montanucci, G. Luca, C. Boselli, G. Noya, B. Barbaro, M. Qi, K.P. Kinzer, J. Oberholzer, R. Calafiore. Diabetes Care 34 (2011) 2406-2409.

19. R. Calafiore, G. Basta, G. Luca, A. Lemmi, M.P. Montanucci, G. Calabrese, L. Racanicchi, F. Mancuso, P. Brunetti. Diabetes Care 29 (2006) 137-138.

20. R. Calafiore, G. Basta, G. Luca, A. Lemmi, L. Racanicchi, F. Mancuso, M.P. Montanucci, P. Brunetti, Transplant. Proc. 38 (2006) 1156-1157.

21. B.E. Tuch, G.W. Keogh, L.J. Williams, W. Wu, J.L. Foster, V. Vaithilingam, R. Philips. Diabetes Care 32 (2009) 1887-1889.

22. T. Kobayashi, Y. Aomatsu, H. Iwata, T. Kin, H. Kanehiro, M. Hisanaga, S. Ko, M. Nagao, Y. Nakajima. Transplantation 75 (2003) 619-625.

23. D.Y. Lee, S.J. Park, S. Lee, J.H. Nam, Y. Byun. Tissue Eng. 13 (2007) 2133-2141.

24. H. Dong, T.M. Fahmy, S.M. Metcalfe, S.L. Morton, X. Dong, L. Inverardi, D.B. Adams, W. Gao, H. Wang. Plos One 7 (2012) e50265.

25. P. Soon-Shiong, E. Feldman, R. Nelson, R. Heintz, Q. Yao, Z. Yao, T. Zheng, N. Merideth, G. Skjak-Braek, T. Espevik. Proc. Natl. Acad. Sci. USA 90 (1993) 5843-5847. 
26. P. Soon-Shiong, R.E. Heintz, N. Merideth, Q.X. Yao, Z. Yao, T. Zheng, M. Murphy, M.K. Moloney, M. Schmehl, M. Harris, R. Mendez, R. Mendez, P.A. Sandford. Lancet 343 (1994) 950-951.

27. R.B. Elliot, O. Garkavenko, P. Tan, N.N. Skaletsky, A. Guliev, B. Draznin, $70^{\text {th }}$ Scientific Sessions, American Diabetes Association. Orlando, Florida, USA, 2010.

28. R.B. Elliott, L. Escobar, P.L. Tan, M. Muzina, S. Zwain, C. Buchanan. Xenotransplantation 14 (2007) 157-161.

29. V.F. Duvivier-Kali, A. Omer, M.D. Lopez-Avalos, J.J. O'Neil, G.C. Weir. Am. J. Transplant. 4 (2004) 1991-2000.

30. K. Suzuki, S. Bonner-Weir, N. Trivedi, K.H. Yoon, J. Hollister-Lock, C.K. Colton, G.C. Weir. Transplantation 66 (1998) 21-28.

31. W.J. Tze, S.C. Cheung, J. Tai, H. Ye. Transplant. Proc. 30 (1998) 477-478.

32. A. King, J. Lau, A. Nordin, S. Sandler, A. Andersson. Diabetes Technol. Ther. 5 (2003) 653-663.

33. T. Espevik, M. Otterlei, G. Skjak-Braek, L. Ryan, S.D. Wright, A. Sundan. Eur. J. Immunol. 23 (1993) 255-261.

34. M. Otterlei, K. Ostgaard, G. Skjak-Braek, O. Smidsrod, P. Soon-Shiong, T. Espevik. J. Immunother. 10 (1991) 286-291.

35. R.P. Lanza, R. Jackson, A. Sullivan, J. Ringeling, C. McGrath, W. Kuhtreiber, W.L. Chick. Transplantation 67 (1999) 1105-1111.

36. U. Zimmermann, F. Thurmer, A. Jork, M. Weber, S. Mimietz, M. Hillgartner, F. Brunnenmeier, H. Zimmermann, I. Westphal, G. Fuhr, U. Nöth, A. Haase, A. Steinert, C. Hehdrich. Ann. NY Acad. Sci. 944 (2001) 199-215.

37. S. Sakai, T. Ono, H. Ijima, K. Kawakami. J. Biomater. Sci. Polym. Ed. 14 (2003) 643-652.

38. H. Zimmermann, D. Zimmermann, R. Reuss, P.J. Feilen, B. Manz, A. Katsen, M. Weber, F.R. Ihmig, F. Ehrhart, P. Gessner, M. Behringer, A. Steinbach, L.H. Wegner, V.L. Sukhorukov, J.A. Vásquez, S. Schneider, M.M. Weber, F. Volke, R. Wolf, U. Zimmermann. J. Mater. Sci. Mater. Med. 16 (2005) 491-501.

39. B. Kulseng, B. Thu, T. Espevik, G. Skjak-Braek. Cell Transplant. 6 (1997) 387-394.

40. Y.A. Morch, I. Donati, B.L. Strand, G. Skjak-Braek. Biomacromolecules 7 (2006) 1471-1480.

41. A. King, S. Sandler, A. Andersson. J. Biomed. Mater. Res. 57 (2001) 374-383.

42. A.M. Rokstad, O.L. Brekke, B. Steinkjer, L. Ryan, G. Kollarikova, B.L. Strand, G. Skjak-Braek, I. Lacik, T. Espevik, T.E. Mollnes. Acta Biomater. 7 (2011) 2566-2578.

43. G.M. Vandenbossche, M.E. Bracke, C.A. Cuvelier, H.E. Bortier, M.M. Mareel, J.P. Remon. J. Pharm. Pharmacol. 45 (1993) 121-125.

44. S. Juste, M. Lessard, N. Henley, M. Menard, J.P. Halle. J. Biomed. Mater. Res. A 72 (2005) 389-398.

45. M.E. Pueyo, S. Darquy, F. Capron, G. Reach. J. Biomater. Sci. Polym. Ed. 5 (1993) 197-203.

46. B.L. Strand, T.L. Ryan, P. In't Veld, B. Kulseng, A.M. Rokstad, G. Skjak-Brek, T. Espevik. Cell Transplant. 10 (2001) 263-275.

47. A. Omer, V. Duvivier-Kali, J. Fernandes, V. Tchipashvili, C.K. Colton, G.C. Weir. Transplantation 79 (2005) 52-58. 
48. B. Kulseng, G. Skjak-Braek, L. Ryan, A. Andersson, A. King, A. Faxvaag, T. Espevik. Transplantation 67 (1999) 978-984.

49. P. De Vos, B.J. De Haan, G.H. Wolters, J.H. Strubbe, R. Van Schilfgaarde. Diabetologia 40 (1997) 262-270.

50. K. Jain, S. Asina, H. Yang, E.D. Blount, B.H. Smith, C.H. Diehl, A.L. Rubin. Transplantation 68 (1999) 1693-1700.

51. H. Iwata, T. Takagi, H. Amemiya. Transplant. Proc. 24 (1992) 52.

52. K.C. Yang, Z. Qi, C.C. Wu, Y. Shirouza, F.H. Lin, G. Yanai, S. Sumi. Biochem. Biophys. Res Commun. 393 (2010) 818-823.

53. I.S. Isayeva, B.T. Kasibhatla, K.S. Rosenthal, J.P. Kennedy. Biomaterials 24 (2003) 3483-3491.

54. K.S. Jones, M.V. Sefton, R.M. Gorczynski. Transplantation 78 (2004) 1454-1462.

55. C. Lhommeau, S. Toillon, T. Pith, L. Kessler, C. Jesser, M. Pinget. J. Mater. Sci. Mater. Med. 8 (1997) 163-174.

56. Z. Qi, C. Yamamoto, N. Imori, A. Kinukawa, K.C. Yang, G. Yanai, E. Ikenoue, Y. Shen, Y. Shirouzu, A. Hiura. Cell Transplant. 21 (2012) 525-534.

57. V. Nadithe, D. Mishra, Y.H. Bae. Biotechnol. Bioeng.109 (2012) 2392-2401.

58. H. Aghajani-Lazarjani, E. Vasheghani-Farahani, S.A. Shojaosadati, S. Hashemi-Najafabadi, S. Zahediasl, T. Tiraihi, F. Atyabi. J. Artif. Organs 13 (2010) 218-224.

59. M.V. Sefton. Biomaterials 14 (1993) 1127-1134.

60. G.F. Klomp, S.H. Ronel, H. Hashiguchi, M. D’Andrea, W.H. Dobelle. Trans. Am. Soc. Artif. Intern. Organs 25 (1979) 74-76.

61. L. Kessler, M. Pinget, M. Aprahamian, P. Dejardin, C. Damge. Horm. Metab. Res. 23 (1991) 312-317.

62. T. Maki, J.P. Lodge, M. Carretta, H. Ohzato, K.M. Borland, S.J. Sullivan, J. Staruk, T.E. Muller, B.A. Solomon, W.L. Chick, A.P. Monaco. Transplantation 55 (1993) 713-717.

63. I.S. Sun, W. Parisius, G.M. Healy, I. Vacek, H.G. Macmorine. Diabetes 26 (1977)1136-1139.

64. S.H. Lee, E. Hao, A.Y. Savinov, I. Geron, A.Y. Strongin, P. Itkin-Ansari. Transplantation 87 (2009) 983-991.

65. A.K. Sorenby, M. Kumagai-Braesch, A. Sharma, K.R. Hultenby, A.M. Wernerson, A.B. Tibell. Transplantation 86 (2008) 364-366.

66. R.L. Geller, T. Loudovaris, S. Neuenfeldt, R.C. Johnson, J.H. Brauker. Ann. NY Acad. Sci. 831 (1997) 438-451.

67. J. Brauker, L.A. Martinson, S.K. Young, R.C. Johnson. Transplantation 61 (1996) 1671-1677.

68. J.H. Brauker, V.E. Carr-Brendel, L.A. Martinson, J. Crudele, W.D. Johnston, R.C. Johnson. J. Biomed. Mater. Res. 29 (1995) 1517-1524.

69. C.K. Colton. Cell Transplant. 4 (1995) 415-436.

70. D.W. Scharp, C.J. Swanson, B.J. Olack, P.P. Latta, O.D. Hegre, E.J. Doherty, F.T. Gentile, K.S. Flavin, M.F. Ansara, P.E. Lacy. Diabetes 43 (1994) 1167-1170.

71. D.W. Scharp, N.S. Mason, R.E. Sparks. World J. Surg. 8 (1984) 221-229.

72. C.A. Hoesli, M. Luu, J.M. Piret, Biotechnol. Prog. 25 (2009) 1740-1751.

73. J.L. Dulong, C. Legallais, S. Darquy, G. Reach. Biotechnol. Bioeng. 78 (2002) 576-582. 
74. T. Zekorn, M. Renardy, H. Planck, P. Zschocke, R.G. Bretzel, U. Siebers, K. Federlin. Horm. Metab. Res.Suppl. 25 (1990) 202-206.

75. J.J. Altmah. J. Diabet. Complications 2 (1988) 68-74.

76. P. Icard, F. Penfornis, C. Gotheil, J. Boillot, C. Cornec, F. Barrat, J.J. Altman. Transplant. Proc. 22 (1990) 724-726.

77. R.P. Lanza, K.M. Borland, J.E. Staruk, M.C. Appel, B.A. Solomon, W.L. Chick. Endocrinology 131 (1992) 637-642.

78. R.P. Lanza, K.M. Borland, P. Lodge, M. Carretta, S.J. Sullivan, T.E. Muller, B.A. Solomon, T. Maki, A.P. Monaco, W.L. Chick. Diabetes 41 (1992) 886-889.

79. R.P. Lanza, D.H. Butler, K.M. Borland, J.M. Harvey, D.L. Faustman, B.A. Solomon, T.E. Muller, R.G. Rupp, T. Maki, A.P. Monaco. Transplant. Proc. 24 (1992) 669-671.

80. P.E. Lacy, O.D. Hegre, A. Gerasimidi-Vazeou, F.T. Gentile, K.E. Dionne. Science 254 (1991) 1782-1784.

81. P. Prevost, S. Flori, C. Collier, E. Muscat, E. Rolland. Transplant. Proc. 27 (1995) 3393-3395.

82. A.S. Rivereau, S. Darquy, L. Chaillous, S. Maugendre, E. Gouin, G. Reach, P. Sai. Diabetes. Metab. 23 (1997) 205-212.

83. J. Schrezenmeir, L. Gero, C. Laue, J. Kirchgessner, A. Muller, A. Huls, R. Passmann, H.J. Hahn, L. Kunz, W. Mueller-Klieser. Transplant. Proc. 24 (1992) 2925-2929.

84. R. Cornolti, M. Figliuzzi, A. Remuzzi. Cell Transplant. 18 (2009) 195-201.

85. W.L. Chick, J.J. Perna, V. Lauris, D. Low, P.M. Galletti, G. Panol, A.D. Whittemore, A.A. Like, C.K. Colton, M.J. Lysaght. Science 197 (1977) 780-782.

86. A.D. Whittemore, W.L. Chick, P.M. Galletti, J.A. Mannick. Surg. Forum. 28 (1977) 93-97.

87. K. Tatarkiewicz, E. Sitarek, M. Sabat, T. Orlowski. Transplant. Proc. 28 (1996) 831-832.

88. H. Ohgawara, J. Miyazaki, S. Karibe, N. Katagiri, F. Tashiro, T. Akaike. Transplant. Proc. 27 (1995) 3319-3320.

89. L. Kessler, M. Aprahamian, M. Keipes, C. Damge, M. Pinget, D. Poinsot. Biomaterials 13 (1992) 44-49.

90. A.D. Whittemore, W.L. Chick, P.M. Galletti, A.A. Like, C.K. Colton, M.J. Lysaght, P.D. Richardson. Trans. Am. Soc. Artif. Intern. Organs 23 (1977) 336-341.

91. P. De Vos, J.L. Hillebrands, B.J. De Haan, J.H. Strubbe, R. Van Schilfgaarde. Transplantation 63 (1997) 824-830.

92. J.H. Juang, S. Bonner-Weir, Y. Ogawa, J.P. Vacanti, G.C. Weir. Transplantation 61 (1996) 1557-1561.

93. A. Pileggi, R.D. Molano, C. Ricordi, E. Zahr, J. Collins, R. Valdes, L. Inverardi. Transplantation 81 (2006) 1318-1324.

94. R. Valdes, S. Martin, A. Cravioto, J. Tenopala. Transplant. Proc. 30 (1998) 481.

95. C.K. Colton, E.S. Avgoustiniatos. J. Biomech. Eng. 113 (1991) 152-170.

96. S. Hirotani, H. Ohgawara, T. Agishi, T. Akaike, S. Miyazaki. Transplant. Proc. 30 (1998) 485-489.

97. A. Andersson, D.L. Eizirik, C. Hellerstrom, R.C. Johnson, D.G. Pipeleers. Transplant. Proc. 26 (1994) 802-803.

98. E. Rafael, A. Wernerson, P. Arner, G.S. Wu, A. Tibell. Cell Transplant. 8 (1999) 317-326. 
99. E. Rafael, G.S. Wu, K. Hultenby, A. Tibell, A. Wernerson. Cell Transplant. 12 (2003) 407-412.

100. I. Yakhnenko, W.K.Wong, I.I. Katkov, P. Itkin-Ansari. Cryo. Letters 33 (2012) 518-531.

101. M. Kumagai-Braesch, S. Jacobson, H. Mori, X. Jia, T. Takahashi, A. Wernerson, M. Flodstrom-Tullberg, A. Tibell. Cell Transplant. 22 (2013) 1137-1146.

102. D.J. Borg, E. Bonifacio. Curr. Diab. Rep. 11 (2011) 434-444.

103. N.V. Krishnamurthy, B. Gimi. Crit. Rev. Biomed. Eng. 39 (2011) 473-491.

104. O. Khanna, J.C. Larson, M.L. Moya, E.C. Opara, E.M. Brey. J. Vis. Exp. 66 (2012) pii3388.

105. H. Zimmermann, S.G. Shirley, U. Zimmermann. Curr. Diab. Rep. 7 (2007) 314-320.

106. G.L. Fiszman, A.L. Karara, L.M. Finocchiaro, G.C. Glikin. Electron. J. Biotechnol. 5 (2002) 23-24.

107. A.M. Sun. Methods Enzymol. 137 (1988) 575-580.

108. V.F. Duvivier-Kali, A. Omer, R.J. Parent, J.J. O’Neil, G.C. Weir. Diabetes 50 (2001) 1698-1705.

109. M.K. Nguyen, D.S. Lee. Macromol. Biosci. 10 (2010) 563-579.

110. K.Y. Lee, D.J. Mooney. Chem. Rev. 101 (2001) 1869-1879.

111. G.D. Nicodemus, S.J. Bryant. Tissue Eng. Part B Rev. 14 (2008) 149-165.

112. P. De Vos, J.F. Van Straaten, A.G. Nieuwenhuizen, M.de Groot, R.J. Ploeg, B.J. De Haan, R. Van Schilfgaarde. Diabetes 48 (1999) 1381-1388.

113. Z.L. Xin, S.L. Ge, X.K. Wu, Y.J. Jia, H.T. Hu. World J. Gastroenterol. 11 (2005) 5714-5717.

114. J.T. Wilson, E.L. Chaikof. Adv. Drug Deliv. Rev. 60 (2008) 124-145.

115. D.Y. Lee, K. Yang, S. Lee, S.Y. Chae, K.W. Kim, M.K. Lee, D.J. Han, Y. Byun. J. Biomed. Mater. Res. 62 (2002) 372-377.

116. J.Y. Jang, D.Y. Lee, S.J. Park, Y. Byun. Biomaterials 25 (2004) 3663-3669.

117. S. Krol, S. del Guerra, M. Grupillo, A. Diaspro, A. Gliozzi, P. Marchetti. Nano Lett. 6 (2006) 1933-1939.

118. Y. Teramura, Y. Kaneda, H. Iwata. Biomaterials 28 (2007) 4818-4825.

119. O. Khanna, M.L. Moya, E.C. Opara, E.M. Brey. J. Biomed. Mater. Res. A 95 (2010) 632-640.

120. Y. Teramura, H. Iwata. Transplantation 91 (2011) 271-278.

121. L. Baruch, O. Benny, A. Gilert, M. Ukobnik, O. Ben Itzhak, M. Machluf. Biomed. Microdevices 11 (2009) 1103-1113.

122. G.M. Campo, A. Avenoso, S. Campo, A. D'Ascola, P. Traina, D. Sama, A. Calatroni. J. Cell. Biochem. 106 (2009) 83-92.

123. A. Leung, G. Lawrie, L.K. Nielsen, M. Trau. J. Microencapsul. 25 (2008) 387-398.

124. M. Senzolo, J. Coppell, E. Cholongitas, A. Riddell, C.K. Triantos, D. Perry, A.K. Burroughs. Blood Coagul. Fibrinolysis 18 (2007) 227-236.

125. C.M. Bunger, B. Tiefenbach, A. Jahnke, C. Gerlach, T. Freier, K.P. Schmitz, U.T. Hopt, W. Schareck, E. Klar, P. de Vos. Biomaterials 26 (2005) 2353-2360.

126. E. Pedraza, M.M. Coronel, C.A. Fraker, C. Ricordi, C.L. Stabler. Proc. Natl. Acad. Sci. USA 109 (2012) 4245-4250.

127. S. Mansouri, Y. Merhi, F.M. Winnik, M. Tabrizian. Biomacromolecules 12 (2011) 585-592.

128. J.C. Pickup, Z.L. Zhi, F. Khan, T. Saxl, D.J. Birch. Diabetes Metab. Res. Rev. 24 (2008) 604-610. 
129. J.T. Wilson, W. Cui, E.L. Chaikof. Nano Lett. 8 (2008) 1940-1948.

130. N.M. Luan, Y. Teramura, H. Iwata. Biomaterials 32 (2011) 6487-6492.

131. K. Tatsumi, K. Ohashi, Y. Teramura, R. Utoh, K. Kanegae, N. Watanabe, S. Mukobata, M. Nakayama, H. Iwata, T. Okano. Biomaterials 33 (2012) 821-828.

132. E. Kroon, L.A. Martinson, K. Kadoya, A.G. Bang, O.G. Kelly, S. Eliazer, H. Young, M. Richardson, N.G. Smart, J. Cunningham, A.D. Agulnick, K.A. D'Amour, M.K. Carpenter, E.E. Baetge. Nat. Biotechnol. 26 (2008) 443-452.

133. A.V. Matveyenko, S. Georgia, A. Bhushan, P.C. Butler. Am. J. Physiol. Endocrinol. Metab. 299 (2010) E713-E720.

134. J. Candiello, S.S. Singh, K. Task, P.N. Kumta, I. Banerjee. J. Biol. Eng. 7 (2013) 9.

135. S. Kadam, S. Muthyala, P. Nair, R. Bhonde. Rev. Diabet. Stud. 7 (2010) 168-182.

136. P.K. Ngoc, P.V. Phuc, T.H. Nhung, D.T. Thuy, N.T. Nguyet. Hum. Cell. 24 (2011) 86-95.

137. N.E. Davis, L.N. Beenken-Rothkopf, A. Mirsoian, N. Kojic, D.L. Kaplan, A.E. Barron, M.J. Fontaine. Biomaterials 33 (2012) 6691-6697.

138. V. Chandra, G. Swetha, S. Muthyala, A.K. Jaiswal, J.R. Bellare, P.D. Nair, R.R. Bhonde. Plos One 6 (2011) e20615.

139. M.N. Mason, M.J. Mahoney. Tissue Eng. Part A 15 (2009) 1343-1352.

140. F.F. Zhu, P.B. Zhang, D.H. Zhang, X. Sui, M. Yin, T.T. Xiang, Y. Shi, M.X. Ding, H. Deng. Diabetologia 54 (2011) 2325-2336.

141. R. Maehr, S. Chen, M. Snitow, T. Ludwig, L. Yagasaki, R. Goland, R.L. Leibel, D.A. Melton. Proc. Natl. Acad. Sci. USA 106 (2009) 15768-15773.

142. K. Tateishi, J. He, O. Taranova, G. Liang, A.C. D’Alessio, Y. Zhang. J. Biol. Chem. 283 (2008) 31601-31607.

143. P.A. Lysy, G.C. Weir, S. Bonner-Weir. Stem Cells Transl. Med. 1 (2012) 150-159.

144. P. Blyszczuk, J. Czyz, G. Kania, M. Wagner, U. Roll, L. St-Onge, A.M. Wobus. Proc. Natl. Acad. Sci. USA 100 (2003) 998-1003.

145. O. Korsgren, B. Nilsson. Curr. Opin. Organ. Transplant. 14 (2009) 683-687.

146. A.C. Gruessner. Rev. Diabet. Stud. 8(1) (2011) 6-16.

147. J.A. Shapiro. Rev. Diabet. Stud. 9(4) (2012) 385-406.

148. V. Vaithilingam, J. Oberholzer, G.J. Guillemin, B.E. Tuch. Rev. Diabet. Stud. 7(1) (2010) 62-73.

149. V. Vaithilingam, I.S. Tuch. Rev. Diabet. Stud. 8(1) (2011) 51-67.

150. J. Parkinson, Developing a comprehensive system to protect islet cells and deliver transplants to all with insulin dependence, 2012.

http://www.diabetescare.net/content upclose detail.asp?id=446538

(Accessed July 30, 2013.)

151. G.H. Mao, G.A. Chen, H.Y. Bai, T.R. Song, Y.X. Wang. Biomaterials 30 (2009) 1706-1714.

152. M. Riopel, R. Wang. Front. Biosci. (Landmark Ed.) 19 (2014) 77-90.

153. V.K. Ramiya, M. Maraist, K.E. Arfors, D.A. Schatz, A.B. Peck, J.G. Cornelius. Nat. Med. 6(3) (2000) 278-282.

154. Y. Evron, B. Zimermann, B. Ludwig, U. Barkai, C.K. Colton, G.C. Weir, B. Arieli, S. Maimon, N. Shalev, K. Yavriyants, T. Goldman, Z. Gendler, L. Eizen, P. Vardi, K. Bloch, A. Barthel, S.R. Bornstein, A. Rotem. Horm. Metab. Res. 47(1) (2015) 24-30.

155. F.W. Pagliuca, J.R. Millman, M. Gürtler, M. Segel, A. Van Dervort, J.H. Ryu, Q.P. Peterson, D. Greiner, D.A. Melton. Cell. 159(2) (2014) 428-439. 
156. B. Ludwig, A. Reichel, A. Steffen, B. Zimerman, A.V. Schally, N.L. Block, C.K. Colton, S. Ludwig, S. Kersting, E. Bonifacio, M. Solimena, Z. Gendler, A. Rotem, U. Barkai, S.R. Bornstein. Proc. Natl. Acad. Sci. USA 110(47) (2013) 19054-19058.

157. U. Barkai, G.C. Weir, C.K. Colton, B. Ludwig, S.R. Bornstein, M.D. Brendel, T. Neufeld, C. Bremer, A. Leon, Y. Evron, K. Yavriyants, D. Azarov,

B. Zimermann, S. Maimon, N. Shabtay, M. Balyura, T. Rozenshtein, P. Vardi, K. Bloch, P. de Vos, A. Rotem. Cell Transplant. 22(8) (2013) 1463-1476.

158. F.Y. McWhorter, C.T. Davis, W.F. Liu. Cell. Mol. Life. Sci. 72(7) (2015) 1303-1316.

159. A. Rezania, J.E. Bruin, P. Arora, A. Rubin, I. Batushansky, A. Asadi, S. O'Dwyer, N. Quiskamp, M. Mojibian, T. Albrecht, Y.H. Yang, J.D. Johnson, T.J. Kieffer. Nat. Biotechnol. 32(11) (2014) 1121-1133.

160. E. Motté, E. Szepessy, K. Suenens, G. Stangé, M. Bomans, D. Jacobs-Tulleneers-Thevissen, Z. Ling, E. Kroon, D. Pipeleers. Am. J. Physiol. Endocrinol. Metab. 307(9) (2014) E838-E846.

161. K. Kirk, E. Hao, R. Lahmy, P. Itkin-Ansari. Stem Cell Res. 12(3) (2014) 807-814.

162. S.H. Lee, E. Hao, A.Y. Savinov, I. Geron, A.Y. Strongin, P. Itkin-Ansari. Transplantation 87(7) (2009) 983-991.

163. E. Pedraza, A.C. Brady, C.A. Fraker, R.D. Molano, S. Sukert, D.M. Berman, N.S. Kenyon, A. Pileggi, C. Ricordi, C.L. Stabler. Cell Transplant. 22(7) (2013) 1123-1135.

164. B. Ludwig, B. Zimerman, A. Steffen, K. Yavriants, D. Azarov, A. Reichel, P. Vardi, T. German, N. Shabtay, A. Rotem, Y. Evron, T. Neufeld, S. Mimon, S. Ludwig, M.D. Brendel, S.R. Bornstein, U. Barkai. Horm. Metab. Res. 42(13) (2010) 918-922.

165. B. Ludwig, A. Rotem, J. Schmid, G.C. Weir, C.K. Colton, M.D. Brendel, T. Neufeld, N.L. Block, K. Yavriyants, A. Steffen, S. Ludwig, T. Chavakis, A. Reichel, D. Azarov, B. Zimermann, S. Maimon, M. Balyura, T. Rozenshtein, N. Shabtay, P. Vardi, K. Bloch, P. de Vos, A.V. Schally, S.R. Bornstein, U. Barkai. Proc. Natl. Acad. Sci. USA 109(13) (2012) 5022-5027.

166. T. Neufeld, B. Ludwig, U. Barkai, G.C. Weir, C.K. Colton, Y. Evron, M. Balyura, K. Yavriyants, B. Zimermann, D. Azarov, S. Maimon, N. Shabtay, T. Rozenshtein, D. Lorber, A. Steffen, U. Willenz, K. Bloch, P. Vardi, R. Taube, P. de Vos, E.C. Lewis, S.R. Bornstein, A. Rotem. PLoS One 8(8) (2013) e70150.

167. U. Barkai, G.C. Weir, C.K. Colton, B. Ludwig, S.R. Bornstein, M.D. Brendel, T. Neufeld, C. Bremer, A. Leon, Y. Evron, K. Yavriyants, D. Azarov, B. Zimermann, S. Maimon, N. Shabtay, M. Balyura, T. Rozenshtein, P. Vardi, K. Bloch, P. de Vos, A. Rotem. Cell Transplant. 22(8) (2013) 1463-1476.

168. B. Ludwig, A. Reichel, A. Steffen, B. Zimerman, A.V. Schally, N.L. Block, C.K. Colton, S. Ludwig, S. Kersting, E. Bonifacio, M. Solimena, Z. Gendler, A. Rotem, U. Barkai, S.R. Bornstein. Proc. Natl. Acad. Sci.USA 110(47) (2013) 19054-19058.

169. R. Pareta, J.P. McQuilling, S. Sittadjody, R. Jenkins, S. Bowden, G. Orlando, A.C. Farney, E.M. Brey, E.C. Opara. Pancreas 43(4) (2014) 605-613.

170. O. Khanna, J.J. Huang, M.L. Moya, C.W. Wu, M.H. Cheng, E.C. Opara, E.M. Brey. Microvasc. Res. 90 (2013) 23-29.

171. M.L. Moya, M.R. Garfinkel, X. Liu, S. Lucas, E.C. Opara, H.P. Greisler, E.M. Brey. J. Surg. Res. 160(2) (2010) 208-212. 
172. M. Kumagai-Braesch, S. Jacobson, H. Mori, X. Jia, T. Takahashi, A. Wernerson, M. Flodström-Tullberg, A. Tibell. Cell Transplant. 22(7) (2013) 1137-1146.

173. T.C. Schulz, H.Y. Young, A.D. Agulnick, M.J. Babin, E.E. Baetge, A.G. Bang, A. Bhoumik, I. Cepa, R.M. Cesario, C. Haakmeester, K. Kadoya, J.R. Kelly, J. Kerr, L.A. Martinson, A.B. McLean, M.A. Moorman, J.K. Payne, M. Richardson, K.G. Ross, E.S. Sherrer, X. Song, A.Z. Wilson, E.P. Brandon, C.E. Green, E.J. Kroon, O.G. Kelly, K.A. D'Amour, A.J. Robins. PLoS One 7(5) (2012) e37004.

174. M. Chayosumrit, B. Tuch, K. Sidhu. Biomaterials 31(3) (2010) 505-514.

175. X. Liu, X. Li, N. Zhang, X. Wen. Med. Hypotheses 85(1) (2015) 82-84.

176. P.O. Carlsson, E. Schwarcz, O. Korsgren, K. Le Blanc. Diabetes 64(2) (2015)587-592.

177. Y. Jun, A.R. Kang, J.S. Lee, S.J. Park, D.Y. Lee, S.H. Moon, S.H. Lee. Biomaterials 35(17) (2014) 4815-4826.

178. V. Chandra, G. Swetha, S. Muthyala, A.K. Jaiswal, J.R. Bellare, P.D. Nair, R.R. Bhonde. PLoS One. 6(6) (2011) e20615.

179. J.L. Wilson, M.A. Najia, R. Saeed, T.C. McDevitt. Biotechnol. Bioeng. 111(3) (2014) 618-631.

180. R. Krishnan, M. Alexander, L. Robles, C.E. Foste, J.R. Lakey. Rev. Diabet. Stud. 11(1) (2014) 84-101.

181. S. Bonner-Weir, A. Inada, S. Yatoh, W.C. Li, T. Aye, E. Toschi, A. Sharma, Biochem. Soc. Trans. 36(Pt 3) (2008) 353-356.

182. K. Jeon, H. Lim, J.H. Kim, N.V. Thuan, S.H. Park, Y.M. Lim, H.Y. Choi, E.R. Lee, J.H. Kim, M.S. Lee, S.G. Cho. Stem Cells Dev. 21(14) (2012) 2642-2655.

183. J.F. Habener, V. Stanojevic, Islets 4(3) (2012) 188-198.

184. T. Thatava, Y.C. Kudva, R. Edukulla, K. Squillace, J.G. De Lamo, Y.K. Khan, T. Sakuma, S. Ohmine, A. Terzic, Y. Ikeda. Mol. Ther. 21(1) (2013) 228-239.

185. Y.C. Kudva, S. Ohmine, L.V. Greder, J.R.Dutton, A. Armstrong, J.G. De Lamo, Y.K. Khan, T. Thatava, M. Hasegawa, N. Fusaki, J.M. Slack, Y. Ikeda. Stem Cells Transl. Med. 1(6) (2012) 451-461.

186. F. Pereyra-Bonnet, M.L. Gimeno, N.R. Argumedo, M. Ielpi, J.A. Cardozo, C.A. Giménez, S.H. Hyon, M. Balzaretti, M. Loresi, P. Fainstein-Day, L.E. Litwak, P.F. Argibay. PLoS One 9(6) (2014) e100369.

187. H.M. Shahjalal, N. Shiraki, D. Sakano, K. Kikawa, S. Ogaki, H. Baba, K. Kume, S. Kume. J. Mol. Cell Biol. 6(5) (2014) 394-408.

188. M. Lemper, G. Leuck, Y. Heremans, M.S. German, H. Heimberg, L. Bouwens, L. Baeyens. Cell Death Differ. 22 (2014) 1117-1130.

189. I. Todorov, I. Nair, K. Ferreri, J. Rawson, A. Kuroda, M. Pascual, K. Omori, L. Valiente, C. Orr, I. Al-Abdullah, A. Riggs, F. Kandeel, Y. Mullen. Transplant. Proc. 37(8) (2005) 3420-3421.

190. H. Noguchi, G. Xu, S. Matsumoto, H. Kaneto, N. Kobayashi, S. Bonner-Weir, S. Hayashi. Cell Transplant. 15(10) (2006) 929-938.

191. F.W. Pagliuca, J.R. Millman, M. Gürtler, M. Segel, A. Van Dervort, J.H. Ryu, Q.P. Peterson, D. Greiner, D.A. Melton. Cell 159(2) (2014) 428-439.

192. D.M. Berman, J.J. O'Neil, L.C. Coffey, P.C. Chaffanjon, N.M. Kenyon, P. Ruiz Jr, A. Pileggi, C. Ricordi, N.S. Kenyon. Am. J. Transplant. 9(1) (2009) 91-104. 


\section{Chapter 14}

